\title{
MEDIATING EFFECT OF CORPORATE IMAGE AND STUDENTS' SATISFACTION ON THE RELATIONSHIP BETWEEN SERVICE QUALITY AND STUDENTS' LOYALTY IN TVET HLIS
}

\author{
Sallaudin Hassan ${ }^{1 *}$, Mohd. Farid Shamsudin², Muhammad Asyraf Hasim², \\ Ishamuddin Mustapha1, Jimisiah Jaafar ${ }^{1}$, Khairul Firdaus Adruthdin', \\ Athirah Shukri', Sunitawati Karim ${ }^{1}$, and Rohaizan Ahmad ${ }^{1}$ \\ ${ }^{1}$ Universiti Kuala Lumpur, Malaysian Institute of Industrial Technology (MITEC), Jalan \\ Persiaran Sinaran Ilmu, Bandar Seri Alam, 81750, Pasir Gudang, Johor, Malaysia \\ ${ }^{2}$ Universiti Kuala Lumpur Business School (UBIS), Level 8, Bangunan Yayasan Selangor, \\ No. 74, Jalan Raja Muda Abdul Aziz, 50300 Kuala Lumpur, Malaysia \\ *Corresponding author: sallaudin@unikl.edu.my
}

Published online: 20 March 2019

To cite this article: Hassan, S. Shamsudin, M.F., Hasim, M.A., Mustapha, I., Jaafar, J., Adruthdin, K.F., Shukri, A., Karim, S., and Ahmad, R. (2019). Mediating effect of corporate image and students' satisfaction on the relationship between service quality and students' loyalty in TVET HLIs. Asian Academy of Management Journal, 24(Supp. 1), 93-105. https://doi.org/10.21315/aamj2019.24.s1.7

To link to this article: https://doi.org/10.21315/aamj2019.24.s1.7

\begin{abstract}
The main purpose of this study is to investigate the mediation effect of corporate image and students' satisfaction on the relationship between service quality and students' loyalty in technical vocational and education and training (TVET) of higher learning institutes (HLIS). The respondents of this study were final year students from TVET HLIs in Malaysia. Using proportionate stratified sampling and followed by convenience sampling method, 431 questionnaires were distributed to nine higher TVET institutions. From that, 398 questionnaires were used for data analysis using SPSS version 22 and SmartPLS 3.0. The measurement model showed that the constructs were reliable and valid. Meanwhile, the structural model showed that there is a direct and significance relationship among all constructs. Two mediators were tested in this research which were service quality and corporate image. Bootstrapping procedure indicated that there was a direct and significant effect between latent constructs. The mediating test statistically showed that there was a partial mediation of student satisfaction and corporate image on the relationship between
\end{abstract}

(C) Asian Academy of Management and Penerbit Universiti Sains Malaysia, 2019. This work is licensed under the terms of the Creative Commons Attribution (CC BY) (http://creativecommons. org/licenses/by/4.0/). 
service quality and student loyalty. This research recommended that TVET HLIs should improve the level of service quality, corporate image, and satisfaction to ensure student satisfaction and loyalty.

Keywords: service quality, corporate image, student satisfaction, student loyalty, technical and vocational education and training (TVET)

\section{INTRODUCTION}

The expectation towards technical and vocational education and training (TVET) of higher learning institutes (HLIs) is getting higher. The 11th Malaysia Plan (2016-2020) has highlighted that the quality and quantity of TVET graduates require improvements. In terms of enrolment, TVET institutions are expected to increase the enrolment to 650,000 by 2020 . Even though this is very tough to achieve, it is very critical as this will align with the demand of technical graduates from the industry. At the same time, the higher education industry in Malaysia is getting more competitive. In TVET HLIs alone, there are more than 1,000 institutes from various ministries and agencies (EPU, 2015). The increasing numbers of TVET institutions indicates that the demand for skilled graduates in technical and vocational is increasing as well. Ismail and Zainal Abiddin (2014) highlighted that more attention should be given to the higher technical education. TVET HLIs are not only competing with other non-TVET HLIs, but also among the TVET HLIs. Due to the high competition in the higher learning sector, it is important for TVET HLIs to improve the level of service quality and corporate image. The role of service quality in higher education has received increasing attention in the past two decades. The management of higher education institutes is responsible in ensuring that all services provided to students are managed and well organised to enhance the student's perceived quality service delivery (Usman \& Mokhtar, 2016). Meanwhile, Pérez and Torres (2017) highlighted that corporate image is important for several organisations to be competitive and establish their permanence in the market in the short-, medium- and long-terms, with a growing demand for their products and/or services.

It is very important for the management of TVET HLIs to keep up a good service quality and corporate image since it will affect the level of students' satisfaction. Students as customers are the major concern for an educational institution, and the satisfaction of them shows the success or failure of the institution's operation (Abasimi \& Xiaosong, 2016; Austin \& Pervaiz, 2017). Service quality and corporate image are important constructs in determining satisfaction (Bapat, 2017). Subsequently, students' satisfaction will influence their loyalty (Nguyen \& LeBlanc, 2001). Maintaining students' loyalty is very important. Loyal student 
will retain in the university until completion (Mahadzirah \& Zainudin, 2009), reduce drop out (Duque, 2013), support marketing of university through spreading positive word-of-mouth (Henning-Thurau, Langer, \& Hansen, 2001), and recommend to others (Nguyen \& LeBlanc, 2001). The current literature shows that there is a relationship between service quality, corporate image, satisfaction, and loyalty. However, there is inadequate empirical evidence on the mediating effects between service quality and customer loyalty in the context of TVET HLIs.

This study outlines two research objectives. Firstly, it investigates the mediating effect of student satisfaction on the relationship between service quality and student loyalty. Second, the study investigates the mediating effect of corporate image on the relationship between service quality and student loyalty.

\section{LITERATURE REVIEW}

\section{Service Quality}

The discussion about service quality in higher education is emphasised on the main stakeholder which is students (Gallifa \& Batalle, 2010). There are several instruments to measure service quality such as SERVQUAL, SERVPERV, HEdPERF, EduQUAL, SQM-HEI, and EDUSERVE. This study adapted SERVQUAL model by Parasuraman, Zeithaml, and Berry (1988) which consists of tangible, reliability, assurance, responsiveness, and empathy. SERVQUAL was selected as model for measurement since it can comprehensively measure quality of service. The model is widely applied in several industries such as tourism (Ying, 2015), banking (Ali \& Raza, 2015), healthcare (Meesala \& Paul, 2018), e-commerce (Palese \& Usai, 2018), and higher education (Fitri, Ilias, Abd Rahman, \& Abd Razak, 2008; Ibrahim, Rahman, \& Yasin, 2014). However, the details of measurement items of service quality might slightly be different as to suite with the nature of industry. Previous studies have established the relationship between service quality, satisfaction, and loyalty. Based on Fitri et al. (2008), and Ibrahim et al. (2014), service quality determines students' satisfaction. Meanwhile, studies by Annamdevula and Bellamkonda (2016) and Usman and Mokhtar (2016) highlighted that service quality affects students' loyalty.

\section{Corporate Image}

Bitner (1990) highlighted that image was found to be a major factor in determining the overall evaluation of the organisation. It is the overall impression left in the customer's mind from the accumulative feeling and experience with the 
organisation (Hatch, Schultz, \& Williamson, 2003). While Kotler and Armstrong (2010) stated that image will convey the product or service distinctive benefits and positioning. Thus, corporate image is the overall impression made by the public about the organisation. Kuo and Ye (2009) highlighted that corporate image is wide and its coverage included overall image, institutes' image, and credibility or reputation of the institution. Reputation of the organisation will contribute to the development of the corporate image as well. In the context of this study, corporate image was selected as a construct as it represents the overall views of students towards TVET HLIs. According to Wong (2017) and Nguyen and LeBlanc (2001), corporate image is formed by two main dimensions, which are universities' image and universities' reputation. According to Arpan, Raney, and Zivnuska (2003), academic attributes and news media coverage influence the university's image. On the other hand, Wong (2017) stated that university's reputation consists of fulfilled promises and better reputation as compared to other universities.

\section{Students' Satisfaction}

Burnett (2008) generally described customer's satisfaction as the main key to measure marketing success. Kotler (2003) highlighted that customer's satisfaction is feeling of an individual towards the performance of a product or service. This study measured the overall students' satisfaction, and the concept of students' satisfaction was derived from customers' satisfaction. Measuring students' satisfaction is very important as it is valuable for institution's performance and continuous improvement inclusive of teaching aspect and curriculum design (Nair, Murdoch, \& Mertova, 2011). Thus, the management of TVET HLIs should maximise students' satisfaction since it will affect their loyalty. Kheiry (2012) added that satisfaction of students has direct and positive effects towards their loyalty to the university. Austin and Pervaiz (2017) revealed that there is a relationship between satisfaction of college administration, facilities, and college faculties that will affect students' loyalty.

\section{Students' Loyalty}

Kotler, Armstrong, Harris, and Piercy (2017) defined customer loyalty as being created from good relationship with customers. It is also a result of customers' satisfaction. Heskett, Jones, Loveman, Sasser Jr., and Schlesinger (2008) highlighted that customer's loyalty is a link between behaviour towards product or service and repeat purchase. In the context of this study, customer's loyalty referred to students' loyalty. In the competitive environment, higher education providers should ensure the loyalty of students. Nguyen and LeBlanc (2001) highlighted that loyal student will continue the programme until completion, encourage others, and 
tell positively about the universities. Students' loyalty can also be viewed from the perspective of drop out intention, which is the intention of students to quit from the current university (Duque, 2013). In the context of TVET, Awang, Md. Sail, Alavi, and Ismail (2011) in Malaysia, and Dang and Hathway (2015) in Vietnam, found that there is a relationship between corporate image and students' loyalty. However, the studies were limited to two variables which is do not have the role of mediation effects between the two constructs. Meanwhile, Kuo and Ye (2009) found that students' loyalty is influenced by their satisfaction.

\section{Conceptual Model}

This study integrated corporate image and satisfaction in one framework for measuring the mediating effects between service quality and students' loyalty. There are four main constructs namely Service Quality (SQ), Corporate Image (CI), Students' Satisfaction (SS), and Students' Loyalty (SL). The aim of this research was to test the mediation effect of SS and CI on the relationship between SQ and SL. SQ was the exogenous construct while SS, CI, and SL were the endogenous constructs. This conceptual model pictures five direct relationships which are $\mathrm{SQ} \rightarrow \mathrm{SS}, \mathrm{SQ} \rightarrow \mathrm{CI}, \mathrm{SQ} \rightarrow \mathrm{SL}, \mathrm{SS} \rightarrow \mathrm{SL}$, and $\mathrm{CI} \rightarrow \mathrm{SL}$. The relationships between the constructs are supported by past literature. Research by Usman and Mokhtar (2016) and Bapat (2017) revealed that there is a relationship between service quality and customers' satisfaction. Service quality also affects corporate image (Jiewanto, Laurens, \& Nelloh, 2012; Yilmaz \& Ari, 2017). Meanwhile, research by Ngo and Nguyen (2016) discovered that service quality influenced customers' loyalty. In the context of higher education, students' loyalty is influenced by corporate image of the university (Kheiry, 2012) and students' satisfaction (Usman \& Mokhtar, 2016). Based on the literature review, the following conceptual model (Figure 1) for this study was developed.

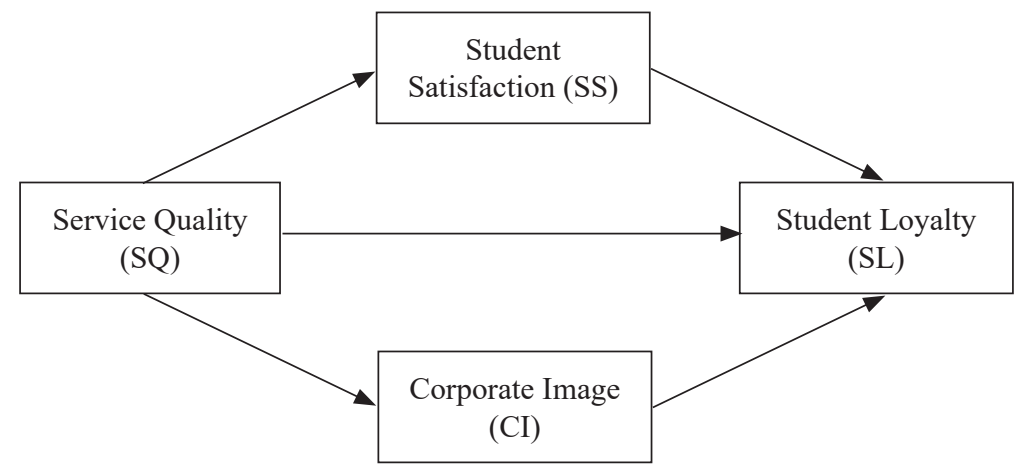

Figure 1. Conceptual model of the mediation effect of SS and CI on the relationship between SQ and SL 
Past studies in various fields have established the direct relationship between the constructs. However, in the context of higher learning, past studies inadequately addressed the mediating effect between the constructs. Thus, this research aimed to examine the mediating effect between SQ and SL in TVET HLIs. To address the research objectives, two hypotheses were developed:

H1: Students' satisfaction mediates the relationship between service quality and students' loyalty.

$\mathrm{H} 2$ : Corporate image mediates the relationship between service quality and students' loyalty.

\section{RESEARCH METHODOLOGY}

This is a quantitative research whereby survey questionnaire was used for data collection. The questionnaire was categorised into five major sections, which were Demographic (A), Service Quality (Part B, 31 items), Corporate Image (Part C, 9 items), Student Satisfaction (Part D, 7 items), and Student Loyalty (Part E, 6 items). Questionnaire was developed based on adaptation from past studies by several scholars, whereby reliability and validity were tested. However, in this study, validity and reliability of the questionnaire were conducted as well. To validate the questionnaire, it was reviewed by six expert panels from four different universities.

The pilot test results showed that the Cronbach's alpha reading exceeded the threshold of 0.7 (Sekaran \& Bougie, 2016). The Cronbach's alpha for SQ was 0.943. This was followed by CI (0.947), SS (9.27), and SL (0.910). Based on these results, full data collection was conducted. The scope of study was TVET HLIs under the Council of Trust for the People (Majlis Amanah Rakyat, MARA) higher education institutes in Malaysia. Students from 10 Universiti Kuala Lumpur (UniKL) campuses were selected. Total population was 18,079 students. To distribute the questionnaires to respondents, random stratified sampling was used. First, stratification was done based on campuses. Then, the questionnaires were distributed randomly in the classroom. Based on Krejcie and Morgan's (1970) table, 375 sample was required. However, 431 questionnaires were distributed. Then, 398 completed questionnaires were used for data analysis using SPSS version 22 and SmartPLS. 


\section{DATA ANALYSIS}

Data analysis for this study used SmartPLS 3.0 software. As per Partial Least Square-Structural Equation Modelling (PLS-SEM) protocol, two main assessment are required to be conducted, which are measurement model and structural model (Hair, Hult, Ringle, \& Sarstedlt, 2017).

\section{Measurement Model Assessment Summary}

\section{Measurement model for formative}

SQ and CI constructs were developed based on formative measurement model. Based on Hair et al. (2017), measurement model for formative constructs involve convergent validity, collinearity, and significance and relevance for formative indicators. Convergent validity involved the assessment of redundancy analysis. Redundancy analysis for SQ and CI achieved above the threshold of 0.7, which was 0.798 and 0.790 , respectively. There was no problem of collinearity for both SQ and CI since the variance inflation factors (VIF) for both SQ and CI was below 5. The next test assessed the level of significance and relevance. Based on Hair et al. (2017), for formative indicators, outer weight and $t$-value were referred first. However, in the case where indicators were not significant, outer loading threshold (above 0.5) was referred to decide for retaining of the indicators. The results showed that some of the indicators achieved a $t$-value less than the threshold of 1.96 but an outer loading of more than 0.5 . Thus, based on outer loading criteria, all items were retained.

\section{Measurement model for reflective}

SS and SL constructs were developed based on reflective model. Both constructs passed convergent validity with loadings more than 0.7 and average variance extracted (AVE) of more than 0.5 . Both constructs also passed internal consistency reliability where the composite reliability and Cronbach's alpha exceeded the 0.6 and 0.7 threshold, respectively. Both constructs also passed Fornell and Larcker's criteria whereby the square root of AVE for each latent variable (LV) was greater than the correlation among the LVs. Cross loading results also showed that the outer loading value was greater than its loading with all other remaining constructs.

\section{Structural Model Assessment Summary}

First, the results of collinearity for all indicators showed that VIF values achieved less than 5. Thus, it indicated that there was no problem of collinearity. Second was 
assessing the significance and relevance of the structural model relationships by looking at $t$-value (more than 1.96). The results showed that there was a significant relationship of SQ $\rightarrow \mathrm{SS}$ (9.493), SQ $\rightarrow \mathrm{SL}$ (1.981), SQ $\rightarrow \mathrm{CI}$ (32.962), and CI $\rightarrow \mathrm{SL}$ (8.071). Third, $\mathrm{R}^{2}$ predictive accuracy level for endogenous variable for $\mathrm{CI}$ and SS were moderate while $\mathrm{R}^{2}$ for SS was high. Fourth, assessment of effect size $\left(f^{2}\right)$ showed that $\mathrm{SQ} \rightarrow \mathrm{CI}$ had a high effect size, SQ $\rightarrow \mathrm{SS}, \mathrm{CI} \rightarrow \mathrm{SS}$, and SS $\rightarrow \mathrm{SL}$ had a medium effect size, while SQ $\rightarrow$ SL and $\mathrm{CI} \rightarrow \mathrm{SL}$ had a low effect size. Overall, all the structural model assessments passed the PLS-SEM criteria.

\section{Mediation Test}

Mediation test was run using SmartPLS 3.0 through bootstrapping steps. Step by step of mediation test was referred to Hair et al. (2017). The mediating test was obtained via "specific indirect effect" result. The result showed that both hypotheses were supported. The $t$-values and $p$-values for both $\mathrm{H} 1$ and $\mathrm{H} 2$ showed significance. The next step was measuring the level of mediation by looking at the variance accounted for (VAF). VAF less than $20 \%$ is considered as no mediation, VAF between $20 \%-80 \%$ is partial mediation, and VAF above $80 \%$ is full mediation. The mediation test is depicted in Table 1 .

Table 1

Mediation test of students' satisfaction and corporate image

\begin{tabular}{llcccccc}
\hline No. & Hypotheses & $\begin{array}{c}\text { Std. } \\
\text { Beta }\end{array}$ & Std. Error & $t$-value & $p$-value & Decision & VAF \\
\hline H1 & SQ $\rightarrow$ SS $\rightarrow$ SL & 0.483 & 0.046 & 10.462 & 0.000 & Supported & $\begin{array}{c}67.8 \% \\
\text { (partial mediation) }\end{array}$ \\
H2 & SQ $\rightarrow$ CI $\rightarrow$ SL & 0.353 & 0.045 & 7.797 & 0.000 & Supported & $\begin{array}{c}49.7 \% \\
\text { (partial mediation) }\end{array}$ \\
\hline
\end{tabular}

\section{DISCUSSION AND CONCLUSION}

Based on the measurement model, all constructs were confirmed as reliable and valid. Meanwhile, the results of structural model indicated that there was a direct and significant relationship between the constructs. Service quality had a direct and significant relationship with students' satisfaction and corporate image. This finding is consistent with earlier research by Usman and Mokhtar (2016) and Yilmaz and Ari (2017). Meanwhile, students' satisfaction and corporate image had a direct and significance relationship with students' loyalty. This finding is consistent with Wong (2017) and Nguyen and LeBlanc (2001). This study also 
revealed that service quality had a direct and significance relationship with students' loyalty, which is consistent with an earlier finding by Ali et al. (2016). Overall, based on these findings, relationships between constructs were tested and established. Thus, mediating test could be conducted.

Mediating test was successfully used to analyse two constructs, i.e., students' satisfaction and corporate image. It was found that the relationship between service quality and students' loyalty was mediated by students' satisfaction. This finding is consistent with earlier research by Meesala and Paul (2018) and Usman and Mokhtar (2016). As to categorise the type of mediation, VAF reading was referred. Since the VAF value of student satisfaction was $68.7 \%$, the mediation type was categorised as partial. Thus, RO1 was met and $\mathrm{H} 1$ supported. The second mediator in this study was corporate image. Based on mediation test, it was found that the relationship between service quality and students' loyalty was also mediated by corporate image. The VAF value for corporate image was $49.7 \%$. Thus, the mediation type was partial. Based on this result, $\mathrm{RO} 2$ was met and $\mathrm{H} 2$ supported.

Based on the finding in this study, there is no doubt that service quality, students' satisfaction, and corporate image are very important factors in students' loyalty in TVET HLIs. Currently, the competition among the HLIs is very competitive and it is very challenging to achieve the enrolment target. This study suggests to TVET HLIs to improve the level of service quality provided to student as their main customers. The main reason is that service quality is empirically proven as main factors that influence students' satisfaction, corporate image, and students' loyalty. Based on the descriptive analysis in this study, more attention should be given to empathy and responsiveness. In dealing with student as main customers, the staff is expected to show sincerity and prompt response towards problems and complaints. Good relationship between staff and student will instil feeling of satisfaction and therefore influence students' loyalty. In another angle, corporate image of TVET HLIs can be improved through linkages with alumni who successfully work with big companies. Positive testimony by the company about the quality of graduates will help to influence a better image and reputation of TVET HLIs. Meanwhile, positive word of mouth by the alumni of TVET HLIs will support to instil students' loyalty.

This study has successfully developed and integrated model that links service quality, corporate image, students' satisfaction, and students' loyalty with two mediators in one framework for TVET HLIs. The research objectives were met, and all hypotheses were supported. However, this finding is limited to higher TVET scope only. It is recommended that future studies consider the extension of the scope of study to other areas. 


\section{ACKNOWLEDGEMENTS}

The authors would like to thank Universiti Kuala Lumpur (UniKL) management who has approved the fund through Short-Term Research Grant (STRG) in year 2017. A special thanks to all team members who supported this project.

\section{REFERENCES}

Abasimi, E. \& Xiaosong, G. (2016). Character strengths and life satisfaction of teachers in Ghana. Humanities and Social Sciences Letters, 4(1), 22-35. https://doi. org/10.18488/journal.73/2016.4.1/73.1.22.35

Abu-ELSamen, A.A., Akroush, M.N., Al-Khawaldeh, F.M., \& Al-Shibly, M.S. (2011). Towards an integrated model of customer service skills and customer loyalty: The mediating role of customer satisfaction. International Journal of Commerce and Management, 21(4), 349-380. https://doi.org/10.1108/10569211111189365

Ali, F., Khan, A., \& Rehman, F. (2012). An assessment of the service quality using gap analysis: A study conducted at Chitral, Pakistan. Interdisciplinary Journal of Contemporary Research in Business, 4(3), 259-266.

Ali, F., Zhou, Y., Hussain, K., Kumar, P., Neethiahnanthan, N., \& Ragavan, A. (2016). Does higher education service quality effect student satisfaction? A study on international student in Malaysia public university. Quality Assurance in Education, 14(3), 251-267.

Ali, M., \& Raza, S. A. (2015). Service quality perception and customer satisfaction in Islamic banks of Pakistan: The modified SERVQUAL model. Total Quality Management \& Business Excellence, 3363(June), 1-19.

Alves, H., \& Raposo, M. (2010). The influence of university image on student behaviour. International Journal of Educational Management, 24(1), 73-85. https://doi. org/10.1108/09513541011013060

Amin, M., \& Isa, Z. (2008). An examination of the relationship between service quality perception and customer satisfaction: A SEM approach towards Malaysian Islamic banking. International Journal of Islamic and Middle Eastern Finance and Management, 1(3), 191-209.

Annamdevula, S., \& Bellamkonda, R.S. (2016). The effects of service quality on student loyalty: The mediating role of student satisfaction. Journal of Modelling in Management, 11(2), 446-462. https://doi.org/10.1108/JM2-04-2014-0031

Arpan, L.M., Raney, A.A., \& Zivnuska, S. (2003). A cognitive approach to understanding university image. Corporate Communications: An International Journal, 8(2), 97-113. https://doi.org/10.1108/1356328031047535

Austin, A.J., \& Pervaiz, S. (2017). The relation between "student loyalty" and "student satisfaction" (a case of college/intermediate students at Forman Christian College). European Scientific Journal, January 2017(Special Edition), 100-117. 
Awang, A.H., Md. Sail, R., Alavi, K., \& Ismail, I.A. (2011). Image and students' loyalty towards technical and vocational education and training. Journal of Technical Education and Training, 3(1), 13-28.

Bapat, D.M. (2017). Exploring the antecedents of loyalty in the context of multi-channel banking. International Journal of Bank Marketing, 35(2), 174-186. https://doi. org/10.1108/IJBM-10-2015-0155

Bitner, M.J. (1990). Evaluating service encounters: The effects of physical surroundings and employee responses. Journal of Marketing, 54(1), 69-82. https://doi. org/10.1177/002224299005400206

Burnett, J. (2008). Core concept of marketing. Zurich, Switzerland: Jacobs Foundation.

Dang, V.H., \& Hathaway, T. (2015). The influence of vocational education training image on students' loyalty: Case study in Vietnam. International Journal of Vocational and Technical Education, 7(5), 40-53.

Duque, L.C. (2013). A framework analyzing higher education performance: Student's satisfaction, perceived learning outcomes and dropout intentions. Total Quality Management \& Business Excellence Journal, 25(1-2), 1-21. https://doi.org/10.1 080/14783363.2013.807677

EPU (Economic Planning Unit). (2015). Strategy Paper 9: Transforming Technical and Vocational Education and Training to Meet Industry Demand. Eleventh Malaysia Plan, 2016-2020: Way Forward, p. 18. Retrieved from http://rmk11.epu.gov.my/ pdf/strategy-paper/StrategyPaper09.pdf.

Fitri, H.A., Ilias, A., Abd Rahman, R., \& Abd Razak, M.Z. (2008). Service quality and student satisfaction: A case study at private higher education institutions. International Business Research, 1(3), 163-175.

Gallifa, J., \& Batalle, P. (2010). Student perceptions of service quality in a multi-campus higher education system in Spain. Quality Assurance in Education, 18(2), 156170. https://doi.org/10.1108/09684881011035367

Hair, J.F., Hult, G.M., Ringle, C.M., \& Sarstedlt, M. (2017). A primer on partial least squares structural modelling (PLS SEM). Thousand Oaks, CA: Sage Publication, Inc.

Haksever, C., Render, B., Russel, R.S., \& Murdick, R.G. (2000). Service management and operations (2nd ed.). New Jersey, NJ: Prentice Hall.

Hatch, M.J., Schultz, M., \& Williamson, J. (2003). Bringing the corporate into corporate branding. European Journal of Marketing, 37(7/8), 104-164. https://doi.org/ 10.1108/03090560310477654

Henning-Thurau, T., Langer, M., \& Hansen, U. (2001). Modelling and managing student loyalty: An approach based on the concept of relationship quality. Journal of Service Research, 3(4), 331-44. https://doi.org/10.1177/109467050134006

Heskett, J.L., Jones, T.O., Loveman, G.W., Sasser Jr., W.E., \& Schlesinger, L.A. (2008). Putting the service-profit chain to work. Harvard Business Review, 86(7-8).

Ibrahim, M.Z., Rahman, M.N.A., \& Yasin, R.M. (2014). Determining factors of students' satisfaction with Malaysian skills training institutes. International Education Studies, 7(6), 9-24. https://doi.org/10.5539/ies.v7n6p9 
Ismail, A., \& Zainal Abiddin, N. (2014). Issues and challenges of technical and vocational education and training in Malaysia towards human capital development. MiddleEast Journal of Scientific Research, 19, 7-11.

Jiewanto, A., Laurens, C. \& Nelloh, L. (2012). Influence of service quality, university image, and student satisfaction toward WOM intention: A case study on Universitas Pelita Harapan Surabaya. Procedia Social and Behavioral Sciences, 40, 16-23. https://doi.org/10.1016/j.sbspro.2012.03.155

Juga, J., Juntunen, J., \& Grant, D. (2010). Service quality and its relation to satisfaction and loyalty in logistics outsourcing relationships. Managing Service Quality, 20(6), 496-510. https://doi.org/10.1108/09604521011092857

Kheiry, B. (2012). University intellectual image impact on satisfaction and loyalty of students (Tehran selected universities). African Journal of Business Management, 6(37), 10205-10211. https://doi.org/10.5897/AJBM11.434

Kotler, P. (2003). Marketing management (11th ed.). New Jersey, NJ: Prentice Hall.

Kotler, P., \& Armstrong, G. (2010). Principles of marketing (13th ed.). New Jersey, NJ: Prentice Hall.

Kotler, P., Armstrong, G., Harris C.L., \& Piercy, N. (2017). Principles of marketing (7th ed.). London: Pearson.

Krejcie, R.V., \& Morgan, D.W. (1970). Determining sample size for research activities. Educational and Psychological Measurement, 30, 607-610. https://doi. org/10.1177/001316447003000308

Kumar, M., Kee, F.T., \& Charles, V. (2010). Comparative evaluation of critical factors in delivering service quality of banks: An application of dominance analysis in modified SERVQUAL model. International Journal of Quality \& Reliability Management, 27(3), 351-377. https://doi.org/10.1108/02656711011023320

Kuo, Y.-K., \& Ye, K.-D. (2009). The causal relationship between service quality, corporate image and adults' learning satisfaction and loyalty: A study of professional training programmes in a Taiwanese vocational institute. Total Quality Management \& Business Excellence, 20(7), 749-762. https://doi. org/10.1080/14783360903037085

Mahadzirah, M., \& Zainudin, A. (2009). Building corporate image and securing student loyalty in the Malaysian higher learning industry. The Journal of International Studies, 4(1), 30-40.

Meesala, A., \& Paul, J. (2018). Service quality, consumer satisfaction and loyalty in hospitals: Thinking for the future. Journal of Retailing and Consumer Services, 40(July), 261-269. https://doi.org/10.1016/j.jretconser.2016.10.011

Nair, C.S., Murdoch, N., \& Mertova, P. (2011). Benchmarking the student experience: The offshore campus experience. The TQM Journal, 23(6), 585-597. https://doi. org/10.1108/17542731111175211

Ngo, V.M., \& Nguyen, H.H. (2016). The relationship between service quality, customer satisfaction and customer loyalty: An investigation in Vietnamese retail banking sector. Journal of Competitiveness, 8(2), 103-116. https://doi.org/10.7441/ joc. 2016.02 .08 
Nguyen, N. (2006). The collective impact of service workers and servicescape on the corporate image formation. International Journal of Hospitality Management, 25(2), 227-44. https://doi.org/10.1016/j.ijhm.2005.06.001

Nguyen, N., \& LeBlanc, G. (2001). Image and reputation of higher education institutions in students' retention decisions. The International Journal of Educational Management, 15(6/7), 303-311. https://doi.org/10.1108/EUM0000000005909

Palese, B., \& Usai, A. (2018). The relative importance of service quality dimensions in e-commerce experiences. International Journal of Information Management, 40(February), 132-140. https://doi.org/10.1016/j.ijinfomgt.2018.02.001

Parasuraman, A., Zeithaml, V.A., \& Berry, L. (1991). Refinement and reassessment of the SERVQUAL scale. Journal of Retailing, 67(4), 420-450.

Parasuraman, A., Zeithaml, V.A., \& Berry, L.L. (1988). SERVQUAL: A multiple-item scale for measuring consumer perceptions of service quality. Journal of Retailing, 64(1), 12-40.

Pérez, J.P., \& Torres, E.M. (2017). Evaluation of the organizational image of a university in a higher education institution. Contaduría y Administración, 62(1), 123-140. https://doi.org/10.1016/j.cya.2016.01.007

Sekaran, U., \& Bougie, R. (2016). Research method for business (7th ed.). United Kingdom: John Wiley \& Sons.

Sohail, M. (2003). Service quality in hospital: More favourable than you might think. Managing Service Quality, 13(3), 197-206. https://doi.org/10.1108/ 09604520310476463

Sohail, M.S., \& Shaikh, N.M. (2004). Quest for excellence in business education: A study of student impressions of service quality. The International Journal of Educational Management, 18(1), 58-65. https://doi.org/10.1108/09513540410512163

Usman U., \& Mokhtar, S.S.M. (2016). Analysis of service quality, university image and student satisfaction on student loyalty in higher education in Nigeria. International Business Management, 10(12), 2490-2502.

Wong, A. (2017). The relationship between institution branding, teaching quality and student satisfaction in higher education in Hong Kong. Journal of Marketing and HR, 4(1), 169-188.

Yilmaz, V., \& Ari, E. (2017). The effects of service quality, image, and customer satisfaction on customer complaints and loyalty in high-speed rail service in Turkey: A proposal of the structural equation model. Transport Science Journal, 13(1), 67-90. https://doi.org/10.1080/23249935.2016.1209255

Ying, K.S. (2015). The mediation effect of value on experience and service quality toward satisfaction in Malaysian tourism industry. PhD dissertation, Universiti Teknologi Malaysia, Malaysia. 